\title{
Addendum to the Building America House Simulation Protocols
}

C. Engebrecht Metzger, E. Wilson, and S. Horowitz National Renewable Energy Laboratory 


\section{NOTICE}

This report was prepared as an account of work sponsored by an agency of the United States government. Neither the United States government nor any agency thereof, nor any of their employees, subcontractors, or affiliated partners makes any warranty, express or implied, or assumes any legal liability or responsibility for the accuracy, completeness, or usefulness of any information, apparatus, product, or process disclosed, or represents that its use would not infringe privately owned rights. Reference herein to any specific commercial product, process, or service by trade name, trademark, manufacturer, or otherwise does not necessarily constitute or imply its endorsement, recommendation, or favoring by the United States government or any agency thereof. The views and opinions of authors expressed herein do not necessarily state or reflect those of the United States government or any agency thereof.

Available electronically at http://www.osti.gov/bridge

Available for a processing fee to U.S. Department of Energy and its contractors, in paper, from:

U.S. Department of Energy Office of Scientific and Technical Information

P.O. Box 62

Oak Ridge, TN 37831-0062

phone: 865.576 .8401

fax: 865.576.5728

email: mailto:reports@adonis.osti.gov

Available for sale to the public, in paper, from:

U.S. Department of Commerce

National Technical Information Service

5285 Port Royal Road

Springfield, VA 22161

phone: 800.553 .6847

fax: 703.605 .6900

email: orders@ntis.fedworld.gov

online ordering: http://www.ntis.gov/ordering.htm 


\title{
Acknowledgments
}

The authors thank the following current and former National Renewable Energy Laboratory staff members for their significant contributions to the development of this document:

\author{
Ren Anderson \\ Dennis Barley \\ Jay Burch \\ Craig Christensen \\ Mark Eastment \\ Xia Fang \\ Rob Guglielmetti \\ Sara Farrar-Nagy \\ Kristin Field \\ Marcia Fratello \\ Michael Gestwick \\ Robert Hendron \\ Ron Judkoff \\ Neal Kruis \\ Ben Polly \\ Stacey Rothgeb \\ Jennifer Scheib \\ Paul Torcellini \\ Jon Winkler \\ Gail Werren \\ Stefanie Woodward
}

The authors would also like to thank Ed Hancock, Greg Barker, and Paul Reeves for their valuable technical contributions. In addition, the simulation experts for each of the Building America teams provided important new perspectives and critical assistance with the development of these protocols. Finally, we would like to express our gratitude to David Lee, Eric Werling, and Sam Rashkin of the U.S. Department of Energy for the program leadership and financial resources needed to complete this work over many years. 


\title{
Addendum to the Building America House Simulation Protocols
}

\author{
Prepared for: \\ The National Renewable Energy Laboratory \\ On behalf of the U.S. Department of Energy's Building America Program \\ Office of Energy Efficiency and Renewable Energy \\ 15013 Denver West Parkway \\ Golden, CO 80401 \\ NREL Contract No. DE-AC36-08GO28308 \\ Prepared by: \\ C. Engebrecht Metzger, E. Wilson, and S. Horowitz \\ National Renewable Energy Laboratory \\ 15013 Denver West Parkway \\ Golden, CO 80401
}

December 2012 


\section{Definitions}

$\begin{array}{ll}\text { AFUE } & \text { Annual Fuel Utilization Efficiency } \\ \text { ASHRAE } & \text { American Society of Heating, Refrigerating and Air-Conditioning Engineers } \\ \text { ASTM } & \text { American Society for Testing and Materials } \\ \text { BA } & \text { Building America } \\ \text { CEC } & \text { California Energy Commission } \\ \text { CFA } & \text { conditioned floor area } \\ \text { cfm } & \text { cubic feet per minute } \\ \text { COU } & \text { coefficient of utilization } \\ \text { DOE } & \text { U.S. Department of Energy } \\ \text { DOE-2 } & \text { building energy analysis program that can predict the energy use and cost for } \\ \text { EF } & \text { all types of buildings } \\ \text { HSP } & \text { energy factor } \\ \text { IECC } & \text { House Simulation Protocols } \\ \text { IESNA } & \text { International Energy Conservation Code } \\ \text { MAT } & \text { Illuminating Engineering Society of North America } \\ \text { MEL } & \text { monthly average temperature } \\ \text { NCTH } & \text { miscellaneous electric load } \\ \text { NREL } & \text { New Construction Test Home } \\ \text { NREMD } & \text { National Renewable Energy Laboratory } \\ \text { SEER } & \text { National Residential National Residential Efficiency Measures Database } \\ \text { SLA } & \text { seasonal energy efficiency ratio } \\ & \text { specific leakage area } \\ & \end{array}$




\section{Contents}

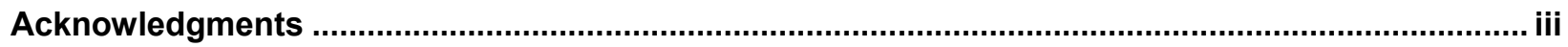

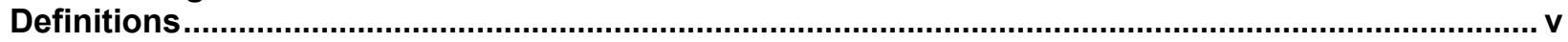

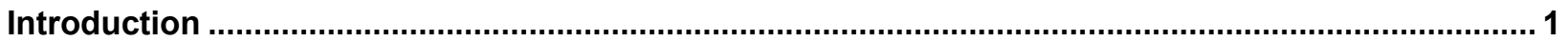

Purpose of the House Simulation Protocols ............................................................................. 1

Purpose of the Addendum to the House Simulation Protocols...............................................2

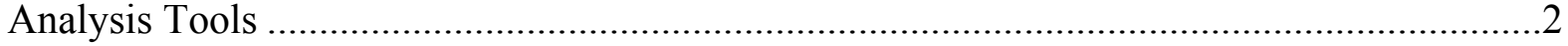

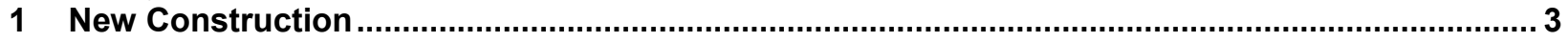

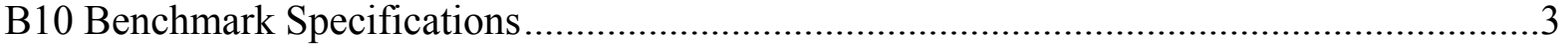

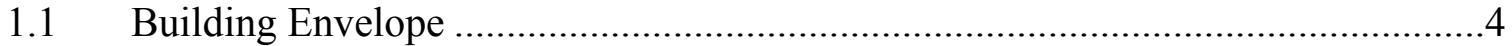

1.2 Space Conditioning/Air Distribution Equipment............................................6

1.3 Domestic Hot Water ...................................................................................... 7

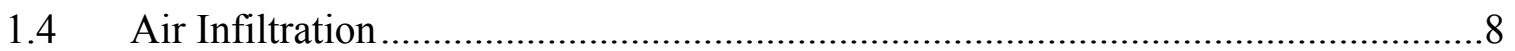

1.5 Mechanical Ventilation ............................................................................

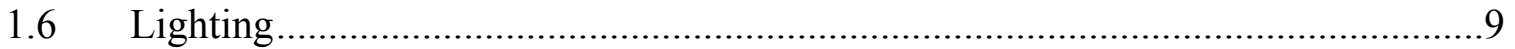

1.7 Appliances and Miscellaneous Electric Loads ..................................................9

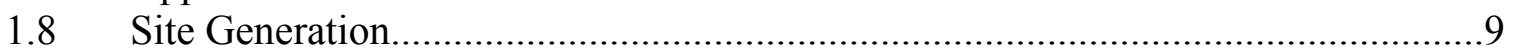

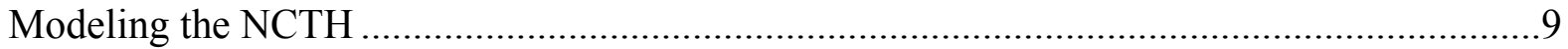

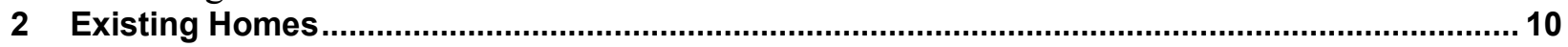

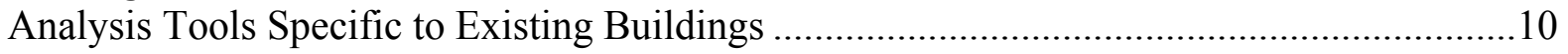

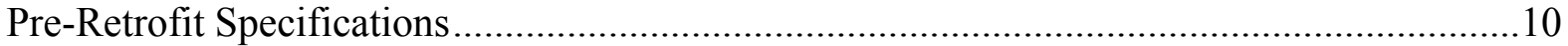

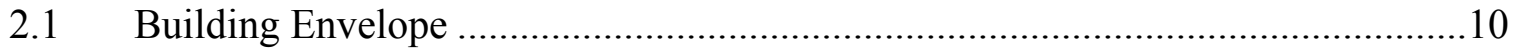

2.2 Space Conditioning/Air Distribution Equipment............................................. 11

2.3 Domestic Hot Water ................................................................................... 11

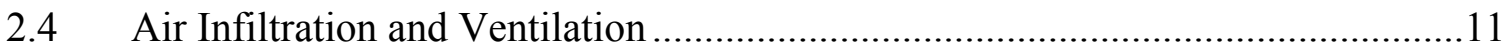

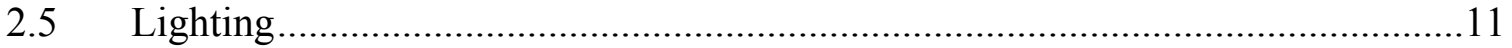

2.6 Appliances and Miscellaneous Electric Loads ..............................................11

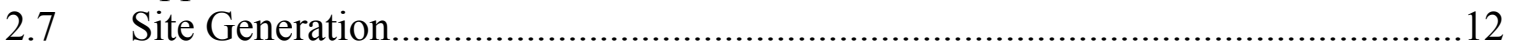

Modeling the Post-Retrofit Case ................................................................................. 12

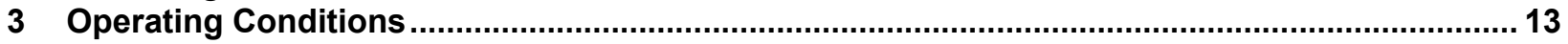

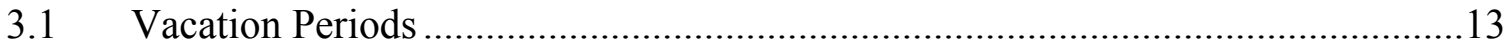

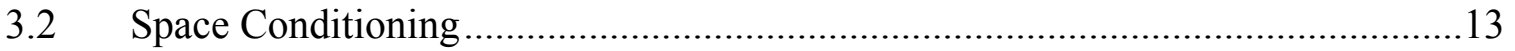

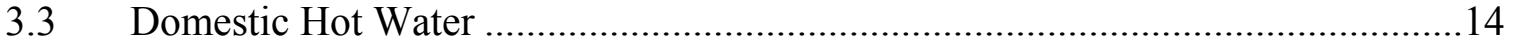

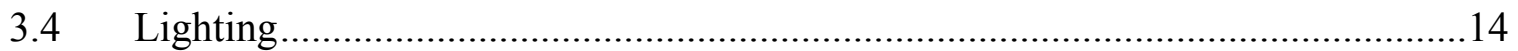

3.5 Appliances and Miscellaneous Electric Loads ................................................14

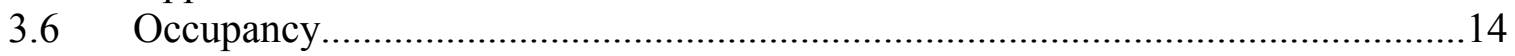

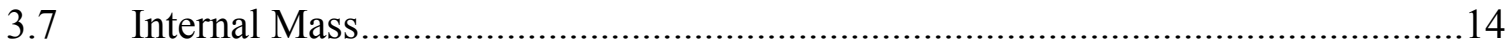

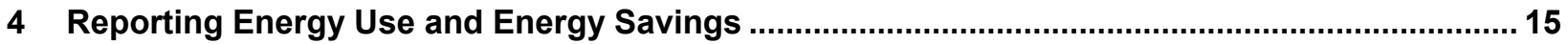

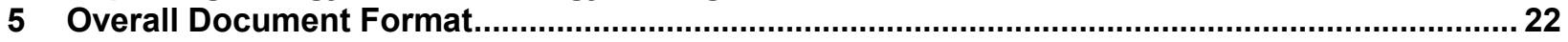

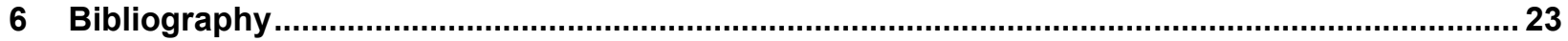




\section{List of Tables}

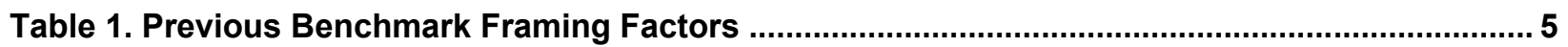

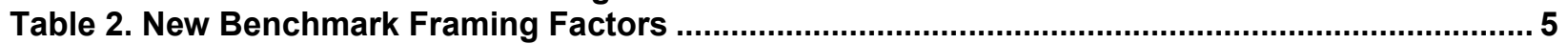

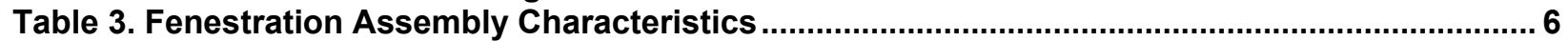

Table 4. Benchmark Space Conditioning Equipment Efficiencies ................................................... 6

Table 5. Benchmark Domestic Hot Water Storage and Burner Capacity ......................................... 7

Table 6. Determination of Benchmark Water Heater Location .......................................................... 8

Table 7. Benchmark Ventilation Specifications .............................................................................. 9

Table 8. Natural Ventilation Seasonal Temperature Limits ......................................................... 13

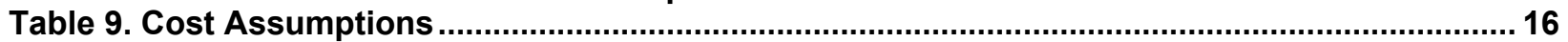

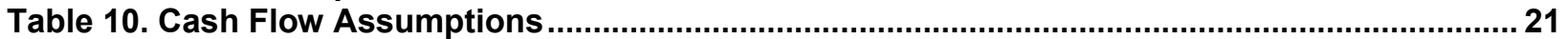




\section{Introduction}

Building America (BA) is an industry-driven research program sponsored by the U.S. Department of Energy (DOE) that applies systems engineering approaches to accelerate the development and adoption of advanced building energy technologies in new and existing residential buildings. This program supports multiple building research teams in the production of advanced residential buildings on a community scale. These teams use a systems engineering process to perform cost and performance assessments to improve each builder or retrofit contractor's standard practice; the overall goal is to significantly reduce energy use with only a nominal increase in initial construction costs. The energy efficiency concepts incorporated into these houses are evaluated by conducting successive design, test, redesign, and retest iterations. This process results in innovations that can be used cost effectively in production-scale housing.

Additional goals of the BA program are to:

- Encourage a systems engineering approach in the design and construction of new homes and retrofits.

- Accelerate the development and adoption of high performance residential energy systems.

- Improve indoor air quality, comfort, and durability.

- Integrate clean onsite power systems.

\section{Purpose of the House Simulation Protocols}

As BA has grown to include a large and diverse cross-section of the home building and retrofit industries, it has become more important to develop accurate, consistent analysis techniques to measure progress towards the program's goals. The House Simulation Protocol (HSP) document provides guidance to program partners and managers so they can compare energy savings for new construction and retrofit projects. The HSP provides the program with analysis methods that are proven to be effective and reliable in investigating the energy use of advanced energy systems and of entire houses.

The HSP document is divided into three sections.

- Section 1 provides information about program design assumptions and analysis methods for new construction. In new construction, the project house (also known as prototype, or New Construction Test Home [NCTH]) is compared to a reference building that represents a "typical" code-built house at the time of the contract recompetition. The most recent contract recompetition was in 2010, so this benchmark house is referred to as the "B10 Benchmark" hereafter in this document.

- Section 2 provides similar information for the analysis of existing homes, including design assumptions and analysis methods for comparing pre-retrofit to post-retrofit homes. Using as many aspects of the real house as possible, this section also provides default values for components of an existing house with unknown performance characteristics. 
- Section 3 provides information about standard operating conditions for the analysis of new and existing homes. Standard user profiles, which represent an average of many occupants rather than actual profiles for an average or typical set of occupants, were developed based on review of the available literature.

\section{Purpose of the Addendum to the House Simulation Protocols}

Traditionally, the HSP has been updated annually to incorporate newly available research results. This year, BA is taking a new approach to this update, in which an addendum to the changes is released first. A public comment period will be offered so the changes can be tested and vetted before they are final.

Specifically, one of the major goals this year for the HSP is to provide the opportunity to plot the benchmark building on BEopt optimization curves (Christensen et al. 2006) ${ }^{1}$. To do this, it is necessary to have physical options that can have costs associated with each measure.

Fortunately, NREL also recently developed the National Residential Efficiency Measures Database (NREMD), which includes costs for all types of measures. View the NREMD at: http://www.nrel.gov/ap/retrofits/about.cfm.

This addendum follows the same structure as the HSP and notes cases in which no changes were made.

\section{Analysis Tools}

A key decision in any building energy analysis is determining which tool or program to use to estimate energy consumption. An hourly simulation is often necessary to fully evaluate the timedependent energy impacts of advanced systems used in BA houses. Thermal mass, solar heat gain, and wind-induced air infiltration are examples of time-dependent effects that can be accurately modeled only by using a model that calculates heat transfer and temperature in short time intervals. An hourly simulation program is also necessary to accurately estimate peak energy loads. Because it has been specifically developed and tailored to meet BA's needs, BEopt (using either DOE-2 or EnergyPlus as the simulation engine) is the hourly simulation tool recommended for systems analysis studies performed under the DOE BA program.

The BA teams are also encouraged to use other simulation tools when appropriate for specialized building simulation analysis (new technologies, some multifamily projects, etc.), provided the tool has met the requirements of the Building Energy Simulation Test and Diagnostic Method in accordance with the software certification sections of RESNET (2006). Regardless of the tool selected, teams should present complete analysis results in their final project summaries.

\footnotetext{
${ }^{1}$ The National Renewable Energy Laboratory (NREL) developed BEopt to simulate residential building energy performance.
} 


\section{New Construction}

To track progress toward aggressive multiyear, whole-house energy savings goals of $30 \%-50 \%$ for new homes, NREL developed the concept of a new construction reference building that represents the "typical" code-built house at the time of the contract recompetition. The most recent contract recompetition was in 2010, so this reference building is called the "B10 Benchmark" or "Benchmark" in this document. This reference building is generally consistent with the 2009 International Energy Conservation Code (IECC), with additional definitions that enable the analyst to evaluate all residential end uses consistent with typical homes built in 2010.

The goal is to essentially maintain the energy performance of the Benchmark construction throughout the contract period (in this case, through the end of calendar year 2014). However, updating the HSP is beneficial when a statement needs further clarification, or when more accurate information becomes available through research. These types of changes do not affect the overall reference point-in-time of the building.

A series of user profiles, intended to be an average over many homes, rather than the behavior of an individual set of typical occupants, was created for use in conjunction with the Benchmark. The Benchmark is intended for use with detached and attached single-family housing, as well as multifamily housing.

The following house designs shall be included as part of the analysis of a new home design:

B10 Benchmark. A reference case representing a house built to the 2009 IECC, as well as the federal appliance standards in effect as of January 1, 2010, and lighting characteristics and miscellaneous electric loads (MELs) most common in 2010. The Benchmark is used as the point of reference for tracking progress toward multiyear energy savings goals established by BA.

NCTH. A research home or prototype home built as part of a community-scale project that includes advanced systems and design features built as part of the BA program.

\section{B10 Benchmark Specifications}

The following sections summarize the Benchmark definition. NREL and other BA partners have also developed a series of tools, including spreadsheets with detailed hourly energy use and load profiles, to help analysts quickly and consistently apply the Benchmark. These tools are available on the BA website

(http://www1.eere.energy.gov/buildings/residential/ba house simulation.html). BEopt can also automatically simulate the Benchmark when the specifications for an NCTH are entered.

The Benchmark may be applied to either a single-family or a multifamily home. A single-family home is contained within walls that go from the basement or the ground floor (if there is no basement) to the roof. A single-family attached home is defined as a residence that shares one or more walls with another unit. This definition includes, but is not limited to, duplexes, row houses, and townhomes. 
A multifamily home (or multifamily building) has at least five housing units. Each unit must share at least a floor or a ceiling with another unit. ${ }^{2}$ Also, a given multifamily building may have no more than three stories; otherwise, it is considered a commercial building, which is outside the scope of this document. These definitions are consistent with those provided by the DOE Residential Energy Consumption Survey (DOE 2005) database (except the requirement on the number of units).

\subsection{Building Envelope}

\section{Modification 1.1.1-Modeling the Benchmark, Second Bullet}

Language was added to clarify this statement, which now reads, “... and for climate zones 3 through 8, the basement or crawlspace, which shall be unvented and insulated at the walls..." This was simply a clarification of the basement insulation location, which was omitted in previous versions. The crawlspace and basement of the Benchmark will always be unvented and the floor will not be insulated in any case. Climate zones 1 and 2 will have unvented crawlspaces but no insulation anywhere.

\section{Modification 1.1.2-Modeling the Benchmark, Fourth Bullet}

The basement wall construction for the Benchmark building will be fixed at 8 in. of concrete instead of being the same type of construction as the NCTH. This decision is driven by the desire to cost a more fixed Benchmark building.

\section{Modification 1.1.3-Modeling the Benchmark, New Bullet}

Because BEopt has added capability, the following new language was added: "Surfaces adjacent to neighboring units (attached walls, floors, and ceilings) shall be modeled as adiabatic for both the Benchmark and NCTH."

\section{Modification 1.1.4-Window Analysis, Option 2}

Currently, option 2 allows for equally distributed window area on each of the four walls (including attached walls). The goal of this analysis technique is to have the glazing influences on energy use become independent of the NCTH orientation. To maintain the goal of the fixed Benchmark building, the front door will now be fixed in the north-facing position, rather than following the NCTH. The latest version of BEopt will use option 2 with a fixed orientation, which will keep the simulation run time as low as possible.

\section{Modification 1.1.5-Insulated Ceiling Analysis}

There is an inherent decrease in attic floor insulation levels near the attic perimeter and roof edges with most common construction practices. In the past, the HSP specified a workaround to model this effect by slightly increasing the ceiling framing factor. BEopt can now calculate the effect of the reduced insulation depth at roof edges, accounting for roof type, roof pitch, eave depth, and insulation thickness.

\footnotetext{
${ }^{2}$ The qualifications for a project being labeled "multifamily" will be discussed in 2013.
} 
Modification 1.1.6-Cathedral Ceilings

To provide similar guidance to the IECC 2009, cathedral ceilings in the reference building (Benchmark in this case) required only R-30 in all climates. After much discussion, it was decided that in the future, all cathedral ceilings in the Benchmark building shall be modeled with the same insulation levels that are required in all other ceilings.

\section{Modification 1.1.7-Attached Walls Analysis}

Going forward, the Benchmark shall be modeled with attached walls where the NCTH has attached walls.

\section{Modification 1.1.8-Benchmark Framing Factors}

The framing factors for the Benchmark wood-framed walls in the HSP have been inconsistent with BEopt (see previous HSP values in Table 1).

Table 1. Previous Benchmark Framing Factors

\begin{tabular}{c|c|c}
\hline Enclosure Element & $\begin{array}{c}\text { Frame Spacing } \\
\text { (in. on center) }\end{array}$ & $\begin{array}{c}\text { Framing Fraction } \\
\text { (\% area) }\end{array}$ \\
\hline Walls (Above Grade) & 16 & $23 \%$ \\
\hline $\begin{array}{c}\text { Floors/Basement Ceiling/Crawlspace } \\
\text { Ceiling }\end{array}$ & 16 & $13 \%$ \\
Ceilings Below Unconditioned Space & 24 & $11 \%$ \\
\hline
\end{tabular}

To make these values consistent and referenceable, wood-framed walls shall have the framing factors listed in Table 2. These are referenced from the ASHRAE (2009). Ceiling framing factors in Table 2 reflect the fact that BEopt now accounts for the attic perimeter insulation taper effect.

Table 2. New Benchmark Framing Factors

\begin{tabular}{|c|c|c|}
\hline Enclosure Element & $\begin{array}{c}\text { Frame Spacing } \\
\text { (in. on center) }\end{array}$ & $\begin{array}{c}\text { Framing Fraction } \\
\text { (\% area) }\end{array}$ \\
\hline $2 \times 4$ Walls (Above Grade) & 16 & $25 \%^{3}$ \\
\hline $2 \times 6$ Walls (Above Grade) & 24 & $22 \%^{3}$ \\
\hline Floors/Basement Ceiling & 16 & $13 \%$ \\
\hline Ceilings Below Unconditioned Space & 24 & $7 \%$ \\
\hline Roof, When Insulated At Roof & 24 & $7 \%$ \\
\hline
\end{tabular}

\footnotetext{
${ }^{3} 2009$ ASHRAE Handbook Fundamentals (I-P Edition), p.27.3
} 


\section{Modification 1.9-Benchmark Fenestration}

Because of the desire to cost the Benchmark, it is important to have the values associated with the Benchmark window properties to be more realistic and to reflect real-world availability and still comply with IECC 2009. Real windows that were chosen were similar for similar climates. (See Table 3.)

Table 3. Fenestration Assembly Characteristics

\begin{tabular}{c|c|c}
\hline Climate Zone & $\begin{array}{c}\text { Vertical Fenestration U-Value } \\
\left(\mathbf{U}_{\mathbf{F}}\right)\left(\mathbf{B t u} / \mathbf{h} \cdot \mathbf{f t}^{\mathbf{2}} \cdot{ }^{\circ} \mathbf{F}\right)\end{array}$ & $\begin{array}{c}\text { Vertical Fenestration } \\
\text { Solar Heat Gain } \\
\text { Coefficient }\end{array}$ \\
\hline 1 to 3 & 0.37 & 0.30 \\
4 to 8 & 0.35 & 0.44 \\
\hline
\end{tabular}

Modification 1.10-Solar Absorptivity of Roofs

The solar absorptivity of roofs shall be equal to 0.85 , which corresponds with medium-colored asphalt shingles. These are some of the most common shingles applied to new construction homes, and the Benchmark building should reflect that.

\subsection{Space Conditioning/Air Distribution Equipment}

Modification 1.2.1-Space Conditioning Equipment Type and Efficiency ${ }^{4}$

In line with the goal to create a fixed Benchmark that can be graphed on a BEopt curve, the space conditioning equipment and fuel types for the Benchmark building are now fixed. (See Table 4 for details.) In the 2010 HSP, an NCTH with electric baseboard heat would be compared to a Benchmark building with a 7.7 heating seasonal performance factor (HSPF)/13 seasonal energy efficiency ratio (SEER) air source heat pump.

Table 4. Benchmark Space Conditioning Equipment Efficiencies

\begin{tabular}{c|c}
\hline Function & Benchmark Space Conditioning Device \\
\hline Heating & $78 \%$ AFUE* gas furnace $^{*}$ \\
Cooling & 13 SEER air conditioner \\
\hline
\end{tabular}

* Annual Fuel Utilization Efficiency

Modification 1.2.2-Stand-Alone Dehumidification

Because research is still being conducted on the issue of universally recommending stand-alone dehumidification in homes, the Benchmark shall not include a stand-alone dehumidifier, regardless of whether the NCTH actively controls relative humidity.

\footnotetext{
${ }^{4}$ This change will be further analyzed in the year 2013 to determine the exact impact on BA analysis.
} 


\section{Modification 1.2.3 - Number of Stories}

The following language will be added to the HSP that states, "For purposes of specifying the Benchmark duct system, the number of stories is defined as each level of living space in the home, including basements (finished and unfinished) and finished attics."

\section{Modification 1.2.4-Duct Return Registers}

To properly cost the Benchmark building, the number of return ducts must be fixed (instead of dependent on NCTH, as currently written). For single-family detached homes, the number of returns is equal to 1 plus the number of stories in the home. For multifamily and attached homes, the number of returns shall be equal to zero, which signifies that the only return is directly into the air handler with no ducts. Values chosen here were based on field experience from the Consortium for Advanced Residential Buildings (CARB), IBACOS, and NREL teams.

\section{Modification 1.2.5-Duct Insulation Levels}

For ducts to be part of a plottable Benchmark house that is not dependent on the options in the $\mathrm{NCTH}$, the insulation levels were changed to R-6 for all duct locations. Previously, the Benchmark building was consistent with IECC 2009, which specified that supply ducts in unconditioned attics have an insulation level of R-8.

\subsection{Domestic Hot Water}

\section{Modification 1.3.1-Hot Water Equipment Type and Efficiency}

Due to the goal of costing the Benchmark building, the Benchmark shall now have a fixed water heating type and efficiency (as opposed to changing depending on the NCTH). The Benchmark shall use a natural gas storage-type water heater, with recovery efficiency of $0.78 .^{5}$ The volume, energy factor (EF), capacity, and tank location are specified in Table 5 and Table 6 . EF must comply with the federal minimum standard $(0.67-0.0019 \times \mathrm{V})$ for the corresponding storage capacity (DOE 2001a). Real combinations of storage capacity, EF, and burner capacity are important for costing, so values in Table 5 were obtained from NREMD.

Table 5. Benchmark Domestic Hot Water Storage and Burner Capacity

\begin{tabular}{c|c|c|c|c|c|c|c}
\hline \# Bedrooms & $\mathbf{1 - 2}$ & \multicolumn{2}{|c|}{$\mathbf{3}$} & \multicolumn{2}{|c|}{$\mathbf{4}$} & $\mathbf{5}$ & $\mathbf{6}$ \\
\hline \# Bathrooms & All & $\leq \mathbf{1 . 5}$ & $\geq \mathbf{2}$ & $\leq \mathbf{2 . 5}$ & $\geq \mathbf{3}$ & All & All \\
\hline Storage (gal) & 30 & 30 & 40 & 40 & 50 & 50 & 50 \\
EF & 0.61 & 0.61 & 0.59 & 0.59 & 0.58 & 0.58 & 0.58 \\
\hline Gas Burner (kBtu/h) & 36 & 36 & 36 & 36 & 38 & 47 & 50 \\
\hline
\end{tabular}

Source: ASHRAE 2007b and NREMD

\footnotetext{
${ }^{5}$ This change will be further analyzed in the year 2013 to determine the exact impact on energy savings models.
} 
Table 6. Determination of Benchmark Water Heater Location

\begin{tabular}{|c|c|}
\hline BA Climate Zone & Benchmark Water Heater Location \\
\hline Hot-Humid, Hot-Dry & $\begin{array}{l}\text { Attached garage if one exists, otherwise in } \\
\text { conditioned space }\end{array}$ \\
\hline $\begin{array}{l}\text { Marine, Mixed-Humid, Cold, } \\
\text { Very Cold, Subarctic }\end{array}$ & Basement if one exists, otherwise in conditioned space \\
\hline
\end{tabular}

\subsection{Air Infiltration}

Modification 1.4.1-Separation of Infiltration and Ventilation

The written HSP document will now have section separation between Infiltration and Mechanical Ventilation.

Modification 1.4.2-SLA to ACH50

Because the ACH50 metric is predominant (compared with specific leakage area [SLA]), the Benchmark air infiltration shall be specified in ACH50. The new Benchmark airtightness metric is $7 \mathrm{ACH} 50$, The teams may now report infiltration in the form of $\mathrm{ACH} 50$.

Equation 6 in the HSP (which references above-ground basement wall area) will be removed. Above-grade basement walls cannot be modeled in BEopt at this time. ${ }^{6}$

\subsection{Mechanical Ventilation}

\section{Modification 1.5.1-Benchmark Ventilation Rate}

To accommodate costing the Benchmark, the ventilation rate for the Benchmark building shall be a single-point exhaust ventilation system, consistent with ASHRAE 62.2.

There is much debate on the appropriate ventilation rate for homes. This is one case where more research is needed. The authors would like the analysts to remember that the Benchmark building is simply a reference point for comparing homes to each other. The ASHRAE 62.2 standard is used because it can be referenced.

\section{Modification 1.5.2-Exhaust Fan Flow Rates in Benchmark}

Previously, some details about exhaust fan flow rates were not clear in the Benchmark specifications. Details are now presented in the HSP (see Table 7).

\footnotetext{
${ }^{6}$ The best workaround for above-grade basement wall area is to increase the wall height of the first floor equal to the above-grade basement wall height.
} 
Table 7. Benchmark Ventilation Specifications

\begin{tabular}{c|c|c|c}
\hline Ventilation Type & Flow Rate $\mathbf{( c f m )}$ & $\begin{array}{c}\text { Power } \\
(\mathbf{W} / \mathbf{c f m})\end{array}$ & Time \\
\hline $\begin{array}{c}\text { Kitchen Spot Exhaust } \\
\text { Bathroom Spot } \\
\text { Exhaust }\end{array}$ & 100 & 0.30 & $6: 00$ p.m.-7:00 p.m. \\
$\begin{array}{c}\text { Whole-House } \\
\text { Ventilation } \\
\text { Clothes Dryer }\end{array}$ & Per ASHRAE 62.2 & 0.30 & $7: 00$ a.m.-8:00 a.m. \\
\hline
\end{tabular}

* Clothes dryer fan power is already included in clothes dryer appliance energy. The authors realize the inconsistancy between the profile of the electricity use (spread out over a day) and ventilation (one hour discrete event) of the clothes dryer. The authors will explore this difference during discussions with the teams in 2013.

The NCTH shall also provide whole-house mechanical ventilation consistent with ASHRAE Standard 62.2, or provide justification otherwise. It is important for the program to require ventilation rates consistent with ASHRAE 62.2 at this time so that decreased ventilation rates are not used as an energy efficiency measure.

\subsection{Lighting}

Modification 1.6.1-Lighting Takeback Effect

Clarification: In all calculations, a takeback is included in the form of an increase in operating hours when incandescent lamps are replaced with energy-efficient lamps (Greening et al. 2000). The takeback factor is proportional to the ratio of the NCTH and Benchmark average efficacies. The modified operating hours are calculated using equation 1:

Operating Hours $=\left[0.9+0.1\left(\frac{\text { Efficacy, } \text { NCTH }}{\text { Efficacy, Benchmark }}\right)\right] \times$ Operating Hours, Benchmark

\subsection{Appliances and Miscellaneous Electric Loads}

Modification 1.7.1-Fixed Appliance Type

Because the goal is to simplify the Benchmark building so that it may be graphed on a BEopt curve, the cooking range and clothes dryer will now be modeled as electric appliances in the Benchmark building, regardless of the NCTH.

\subsection{Site Generation}

No modifications.

\section{Modeling the NCTH}

No modifications. 


\section{Existing Homes}

This section in the HSP provides a set of guidelines for estimating the energy savings achieved by a package of retrofits or an extensive rehabilitation of an existing home. BA developed a set of standard operating conditions that will be used for a building simulation model to objectively compare energy use before and after a series of retrofits is completed. Actual occupant behavior is extremely important for determining the cost effectiveness of a retrofit package, especially if the homeowner is paying the bills. But for tracking progress toward programmatic goals, and for comparing the performance of one house to another, a hypothetical set of occupants with typical behavioral patterns must be used.

Certain field test and audit methods are also described. These tests help establish accurate building system performance characteristics that are needed for a meaningful simulation of whole-house energy use. Several sets of default efficiency values have also been developed for certain older appliances that cannot be easily tested and for which published specifications are not readily available.

\section{Analysis Tools Specific to Existing Buildings}

NREL does not recommend that utility bills be heavily relied on as a tool for model validation in the context of research houses, except as an approximate check of model accuracy. There are two important reasons for this position:

- Occupant behavior is extremely difficult to determine accurately during the period reflected in the utility bills.

- The large number of uncertain input parameters allows multiple ways to reconcile the model with the small number of utility bills, and there is no reliable methodology for performing this calibration because the problem is mathematically undetermined.

Instead, detailed inspections, short-term testing, and long-term monitoring should be used to the greatest extent possible to minimize the uncertainty in model inputs. Default values may be used when certain building features are inaccessible (wall insulation) or efficiency characteristics cannot be readily determined through inspection or short-term testing (furnace AFUE).

Throughout the remainder of this section, the term pre-retrofit case refers to the state of an existing house immediately before it undergoes a series of upgrades, repairs, additions, or renovations. These measures may be limited to a focused set of energy efficiency improvements or may be part of a larger remodeling or gut rehabilitation effort. The term post-retrofit case refers to the same existing house after the package of improvements is complete.

\section{Pre-Retrofit Specifications}

Any element of the pre-retrofit case that is not specifically addressed in the corresponding HSP sections, or is not changed as part of the package of energy efficiency measures, is assumed to be the same as the post-retrofit case.

\subsection{Building Envelope}

No modifications. 


\subsection{Space Conditioning/Air Distribution Equipment Modification 2.2.1-Maintenance Factors}

When true equipment efficiency has not been tested, default values for simulations are provided in the HSP document. Previously, the HSP values projected a decrease in efficiency over time for all types of heating and cooling equipment. Values were dependent on different levels of homeowner maintenance. Further research did not verify whether all types of equipment degrade over time; thus, installation quality may be a more significant performance factor than age. More data are needed in this area.

Until more data are available on the performance of the same installed equipment over many years, the authors have decided to remove the maintenance factor equations.

A point of clarification is the use (or nonuse) of filters. In homes that have no filters or have significant filter bypass, coil fouling can lead to severe equipment degradation. However, because this usually leads to equipment failure and eventual replacement of the filter and cleaning of the coils, the authors have decided not to include this type of incident in the calculation.

The decision is further backed by the requirement of a degradation equation that pertains to a single piece of equipment over its lifetime. With instances of failure and subsequent repair, there is no degradation equation that would capture such neglect.

\subsection{Domestic Hot Water}

No modifications.

\subsection{Air Infiltration and Ventilation \\ Modification 2.4.1-Infiltration Units}

For the same reasons as discussed in the New Construction section, SLA values for existing homes will now be represented as ACH50 values in BEopt.

\subsection{Lighting}

Modification 2.5.1-Lighting Analysis Clarification

If the home is unoccupied at the time of the pre-retrofit lighting audit, the pre-retrofit model should include additional plug-in lighting to meet Illuminating Engineering Society of North America (IESNA) illumination levels (Rea et al. 2000). If the home is occupied at the time of the lighting audit, no additional lighting is necessary; actual installed lighting levels should be used for the analysis.

\subsection{Appliances and Miscellaneous Electric Loads Modification 2.6.1-Default Internal Loads, Table Typographical Errors}

Two typographical errors in the table titled, "Default Internal Loads From Appliances and Small Electric End Uses in the Pre-Retrofit Case" were corrected. MELs sensible load fraction is actually 0.74 and latent load fraction is actually 0.02 . The BA analysis spreadsheet did not have these errors. 


\subsection{Site Generation}

No modifications.

\section{Modeling the Post-Retrofit Case}

Modification-Post-Retrofit Lighting Modeling

Previously, modeled post-retrofit lighting levels were specified to match those in the post-retrofit home. A slight change was made to declare that if the actual post-retrofit lighting levels do not meet IESNA guidelines in an effort to conserve more energy, the post-retrofit home shall be modeled with IESNA lighting levels. 


\section{Operating Conditions}

Operating conditions in the HSP shall apply to all simulations conducted for official BA reporting purposes, including the analysis of new homes and retrofits of existing homes, unless otherwise specified.

\section{Modification 3.1-Modeling Clarification}

For technologies such as ceiling fans that are designed to save energy related to operating conditions, the NCTH may use operating conditions that differ from those required for the Benchmark building. A published reference that proves those specific operating conditions can be changed and maintain occupant comfort, must be included in the analysis section of the related reports for the team to implement those changes in BEopt. The Benchmark shall always use the operating conditions outlined in the HSP.

\subsection{Vacation Periods}

No modifications.

\subsection{Space Conditioning}

Modification 3.2.1-Monthly Average Temperature (MAT) Basis

A clarification was made so that the MAT measurement is less than $66^{\circ} \mathrm{F}$ for heating and greater than or equal to $66^{\circ} \mathrm{F}$ for cooling.

\section{Modification 3.2.2-Dehumidification Simulation}

Because the requirement for blanket stand-alone dehumidification is still in the early research phase, the Benchmark shall not be modeled with a stand-alone dehumidifier, regardless of whether the NCTH actively controls relative humidity.

\section{Modification 3.2.3-Natural Ventilation}

Previously, the logic for the natural ventilation stated that the windows were assumed to be closed once the indoor temperature dropped below $1^{\circ} \mathrm{F}$ above the heating set point. This could lead to overcooling during the heating season. Table 8 shows a new set of parameters that uses natural ventilation more intelligently throughout all seasons.

Table 8. Natural Ventilation Seasonal Temperature Limits

\begin{tabular}{c|c}
\hline Season & $\begin{array}{c}\text { Windows Close If Indoor } \\
\text { Temperature Drops Below: }\end{array}$ \\
\hline Heating Only & $75^{\circ} \mathrm{F}\left(1^{\circ} \mathrm{F}\right.$ below cooling set point $)$ \\
\hline Cooling Only & $72^{\circ} \mathrm{F}\left(1^{\circ} \mathrm{F}\right.$ above heating set point $)$ \\
\hline Both Heating and Cooling Enabled & $72^{\circ} \mathrm{F}\left(1^{\circ} \mathrm{F}\right.$ above heating set point $)$ \\
\hline
\end{tabular}

Windows in BEopt will only open if natural ventilation can meet the cooling load for that hour. 
U.s. DEPARTMENT OF $\mid$ Energy Efficiency \&

ENERCY Renewable Energy

3.3 Domestic Hot Water

No modifications.

\subsection{Lighting}

No modifications.

3.5 Appliances and Miscellaneous Electric Loads

No modifications.

\subsection{Occupancy}

No modifications.

\subsection{Internal Mass}

No modifications. 


\section{Reporting Energy Use and Energy Savings}

\section{Modification 4.1-Cost Assumptions}

The motivation for some of the changes addressed in this report is to respond to the frequent requests made to have real costs associated with the Benchmark building. Table 9 shows the default values for the Benchmark house and their associated costs. These costs can be selected automatically in the BEopt software, by choosing "B10 Benchmark" as the reference building.

There are two possible reasons a category is listed, but no cost is listed: (1) the option (for example, natural ventilation/opening windows) has no associated cost; and (2) it appears in BEopt, and is therefore part of this list, but is not part of the Benchmark building (for example, electric baseboards).

These costs are currently consistent with the NREMD. Because this database is dynamic and changes as more relevant data become available, these values may change over time. However, the units will likely remain consistent. 


\section{Table 9. Cost Assumptions}

\begin{tabular}{|c|c|c|c|c|c|c|c|}
\hline Group & Category & Option & $\begin{array}{c}\text { BA } \\
\text { Zone(s) }\end{array}$ & Cost & $\begin{array}{l}\text { Cost } \\
\text { Units }\end{array}$ & $2^{\text {nd }} \operatorname{Cost}$ & $\begin{array}{c}2^{\text {nd }} \text { Cost } \\
\text { Units }\end{array}$ \\
\hline \multirow{2}{*}{ Building } & Orientation & North & All & 0 & $\$$ & & \\
\hline & Neighbors & North & All & 0 & $\$$ & & \\
\hline \multirow{7}{*}{ Operation } & Heating set point & $71^{\circ} \mathrm{F}$ & All & 0 & $\$$ & & \\
\hline & Cooling set point & $76^{\circ} \mathrm{F}$ & All & 0 & $\$$ & & \\
\hline & Humidity set point & $60 \%$ relative humidity & All & 0 & $\$$ & & \\
\hline & MELs & 1 & All & 0 & $\$$ & & \\
\hline & Miscellaneous gas loads & 1 & All & 0 & $\$$ & & \\
\hline & Natural ventilation & Benchmark & All & 0 & $\$$ & & \\
\hline & Interior shading & Benchmark & All & 0 & $\$$ & & \\
\hline \multirow{10}{*}{ Walls } & Wood Stud & & & & & & \\
\hline & & $\begin{array}{l}\text { R-13 fiberglass batt, Gr-1, } \\
2 \times 4,16 \text { in. o.c. }\end{array}$ & $1,2,3,4$ & 3.4 & \multicolumn{2}{|c|}{$\$ / \mathrm{ft}^{2}$ net exterior wall } & \\
\hline & & $\begin{array}{l}\text { R-21 fiberglass batt, Gr-1, } \\
2 \times 6,24 \text { in. o.c. }\end{array}$ & 7,8 & 3.5 & \multicolumn{2}{|c|}{$\$ / \mathrm{ft}^{2}$ net exterior wall } & \\
\hline & & $\begin{array}{l}\text { R-13 fiberglass batt, Gr-1, } \\
2 \times 4,16 \text { in. o.c., R-5 XPS }\end{array}$ & $4 \mathrm{C}, 5,6$ & 4.4 & \multicolumn{2}{|c|}{$\$ / \mathrm{ft}^{2}$ net exterior wall } & \\
\hline & Double wood stud & None & All & 0 & $\$$ & & \\
\hline & Concrete masonry unit & None & All & 0 & $\$$ & & \\
\hline & $\begin{array}{l}\text { Structurally insulated } \\
\text { panel }\end{array}$ & None & All & 0 & $\$$ & & \\
\hline & Insulating concrete form & None & All & 0 & $\$$ & & \\
\hline & Other & None & All & 0 & $\$$ & & \\
\hline & Exterior finish & Medium/dark stucco ${ }^{7}$ & All & 5.3 & $\begin{array}{c}\$ / \mathrm{ft}^{2} \\
\text { Exterior }\end{array}$ & & \\
\hline
\end{tabular}

\footnotetext{
${ }^{7}$ This default value will be discussed in 2013 to determine the most "standard" across the country
} 


\begin{tabular}{|c|c|c|c|c|c|c|c|}
\hline & & & & & Wall & & \\
\hline & \multicolumn{2}{|c|}{$\begin{array}{l}\text { Interzonal (e.g., between attached garage and } \\
\text { conditioned space) walls }\end{array}$} & & & & & \\
\hline & & $\begin{array}{c}\text { R-13 fiberglass batt, Gr } 1 \\
2 \times 4,16 \text { in. o.c. }\end{array}$ & $1,2,3,4$ & 2.6 & $\$ / \mathrm{ft}^{2}$ wall & & \\
\hline & & $\begin{array}{l}\text { R-21 fiberglass batt, Gr } 1 \text {, } \\
2 \times 6,24 \text { in. o.c. }\end{array}$ & 7,8 & 2.7 & $\$ / \mathrm{ft}^{2}$ wall & & \\
\hline & & $\begin{array}{l}\text { R-13 fiberglass batt, Gr } 1, \\
2 \times 4,16 \text { in. o.c., R-5 XPS }\end{array}$ & $4 \mathrm{C}, 5,6$ & 3.6 & $\$ / \mathrm{ft}^{2}$ wall & & \\
\hline \multirow{10}{*}{$\begin{array}{l}\text { Ceilings/ } \\
\text { Roofs }\end{array}$} & \multicolumn{2}{|l|}{ Unfinished attic } & & & & & \\
\hline & & $\begin{array}{l}\text { Ceiling R-30 cellulose, } \\
\text { vented }\end{array}$ & $1,2,3$ & 0.95 & $\$ / \mathrm{ft}^{2}$ ceiling & & \\
\hline & & $\begin{array}{c}\text { Ceiling R-38 cellulose, } \\
\text { vented }\end{array}$ & $4,4 \mathrm{C}, 5$ & 1.1 & $\$ / \mathrm{ft}^{2}$ ceiling & & \\
\hline & & $\begin{array}{l}\text { Ceiling R-49 cellulose, } \\
\text { vented }\end{array}$ & $6,7,8$ & 1.2 & $\$ / \mathrm{ft}^{2}$ ceiling & & \\
\hline & \multicolumn{2}{|l|}{ Finished roof } & & & & & \\
\hline & & R-30C fiberglass batt, $2 \times 10$ & $1,2,3$ & 2.1 & $\$ / \mathrm{ft}^{2}$ roof & & \\
\hline & & R-38C fiberglass batt, $2 \times 12$ & $4,4 \mathrm{C}, 5$ & 2.7 & $\$ / \mathrm{ft}^{2}$ roof & & \\
\hline & & R-30 + R-19 fiberglass batt & $6,7,8$ & 3.2 & $\$ / \mathrm{ft}^{2}$ roof & & \\
\hline & Roof material & Asphalt shingles, medium & All & 1.8 & $\$ / \mathrm{ft}^{2}$ roof & & \\
\hline & Radiant barrier & None & All & 0 & $\$$ & & \\
\hline \multirow{6}{*}{$\begin{array}{l}\text { Foundation/ } \\
\text { Floors }\end{array}$} & \multicolumn{2}{|l|}{ Slab } & & & & & \\
\hline & & Uninsulated & $1,2,3$ & & & & \\
\hline & & 2-ft R-10 perimeter, R-5 gap & $4,4 \mathrm{C}, 5$ & 1.9 & $\begin{array}{c}\$ / \mathrm{ft}^{2} \text { slab } \\
\text { insulation } \\
\text { (perimeter) }\end{array}$ & 1.2 & $\begin{array}{l}\$ / \mathrm{ft}^{2} \text { gap } \\
\text { insulation }\end{array}$ \\
\hline & & 4-ft R-10 perimeter, R-5 gap & $6,7,8$ & 1.9 & $\begin{array}{c}\$ / \mathrm{ft}^{2} \text { slab } \\
\text { insulation } \\
\text { (perimeter) }\end{array}$ & 1.2 & $\begin{array}{l}\$ / \mathrm{ft}^{2} \text { gap } \\
\text { insulation }\end{array}$ \\
\hline & \multicolumn{2}{|l|}{ Finished Basement } & & & & & \\
\hline & & Uninsulated & $1,2,3$ & & & & \\
\hline
\end{tabular}




\begin{tabular}{|c|c|c|c|c|c|c|c|}
\hline & & $\begin{array}{l}\text { Wall 8-ft R-10 XPS, furring } \\
\text { strips, } 0.5 \text { in. gypsum board }\end{array}$ & $4,4 \mathrm{C}, 5$ & 2.7 & $\$ / \mathrm{ft}^{2}$ wall & & \\
\hline & & $\begin{array}{l}\text { Wall 8-ft R-15 XPS, furring } \\
\text { strips, 0.5-in. gypsum board }\end{array}$ & $6,7,8$ & 3.3 & $\$ / \mathrm{ft}^{2}$ wall & & \\
\hline & \multicolumn{2}{|l|}{ Unfinished Basement } & & & & & \\
\hline & & Uninsulated & $1,2,3$ & & & & \\
\hline & & $\begin{array}{c}\text { Whole Wall, R-10 XPS, } \\
\text { furring strips, } 0.5 \text {-in. gypsum } \\
\text { board }\end{array}$ & $4,4 \mathrm{C}, 5$ & 2.7 & \multicolumn{2}{|c|}{$\$ / \mathrm{ft}^{2}$ basement wall } & \\
\hline & & $\begin{array}{l}\text { Whole Wall, R-15 XPS, } \\
\text { furring strips, } 0.5 \text {-in. gypsum } \\
\text { board }\end{array}$ & $6,7,8$ & 3.3 & \multicolumn{2}{|c|}{$\$ / \mathrm{ft}^{2}$ Basement Wall } & \\
\hline & \multicolumn{2}{|l|}{ Crawlspace } & & & & & \\
\hline & & Uninsulated, vented & 1,2 & & & & \\
\hline & & Wall R-5 XPS, unvented & 3 & 0.84 & $\$ / \mathrm{ft}^{2}$ floor & 0.97 & $\$ / \mathrm{ft}^{2}$ wall \\
\hline & & Wall R-10 XPS, unvented & $\begin{array}{c}4,4 \mathrm{C}, 5,6 \\
7,8\end{array}$ & 0.84 & $\$ / \mathrm{ft}^{2}$ floor & 1.5 & $\$ / \mathrm{ft}^{2}$ wall \\
\hline & Interzonal floor & & & & & & \\
\hline & & $\mathrm{R}-13$ fiberglass batt & 1,2 & 0.68 & $\$ / \mathrm{ft}^{2}$ floor & & \\
\hline & & R-19 fiberglass batt & 3,4 & 0.81 & $\$ / \mathrm{ft}^{2}$ floor & & \\
\hline & & $\mathrm{R}-30$ fiberglass batt & $4 \mathrm{C}, 5,6$ & 1 & $\$ / \mathrm{ft}^{2}$ floor & & \\
\hline & & $\mathrm{R}-38$ fiberglass batt & 7,8 & 1.2 & $\$ / \mathrm{ft}^{2}$ floor & & \\
\hline & Carpet & $80 \%$ carpet & All & 0 & $\$$ & & \\
\hline \multirow{4}{*}{$\begin{array}{l}\text { Thermal } \\
\text { Mass }\end{array}$} & Floor mass & Wood surface & All & 1.8 & $\$ / \mathrm{ft}^{2}$ floor & & \\
\hline & Exterior wall mass & $1 / 2$-in. drywall & All & 1.2 & $\$ / \mathrm{ft}^{2}$ wall & & \\
\hline & Partition wall mass & $1 / 2$ - in. drywall & All & 1.2 & $\$ / \mathrm{ft}^{2}$ wall & & \\
\hline & Ceiling mass & $1 / 2$-in. drywall & All & 1.4 & $\begin{array}{c}\$ / \mathrm{ft}^{2} \\
\text { ceiling }\end{array}$ & & \\
\hline Windows and & Window areas & $15.0 \%$ F25 B25 L25 R25 & All & 0 & $\$$ & & \\
\hline
\end{tabular}

\footnotetext{
${ }^{8}$ This default composition to meet code will be discussed in 2013 to determine the most "standard" across the country
} 


\begin{tabular}{|c|c|c|c|c|c|c|c|}
\hline \multirow[t]{5}{*}{ Doors } & \multicolumn{2}{|l|}{ Windows } & \multirow[b]{2}{*}{$1,2,3$} & \multirow[b]{2}{*}{22} & \multirow[b]{2}{*}{$\begin{array}{c}\$ / \mathrm{ft}^{2} \\
\text { window }\end{array}$} & & \\
\hline & & $\begin{array}{l}\text { Double-pane, low- } \\
\text { gain low-e, nonmetal } \\
\text { frame, air fill }\end{array}$ & & & & & \\
\hline & & $\begin{array}{c}\text { Double-pane, } \\
\text { medium-gain low-e, } \\
\text { nonmetal frame, } \\
\text { argon fill }\end{array}$ & $\begin{array}{c}4,4 \mathrm{C}, 5,6 \\
7,8\end{array}$ & 23 & $\begin{array}{c}\$ / \mathrm{ft}^{2} \\
\text { window }\end{array}$ & & \\
\hline & Eaves & $2 \mathrm{ft}$ & All & 5.8 & $\$ \mathrm{ft}^{2}$ eave & & \\
\hline & Overhangs ${ }^{9}$ & None & All & 0 & $\$$ & & \\
\hline \multirow[t]{2}{*}{ Airflow } & Air leakage & $\begin{array}{c}7 \mathrm{ACH} 50,0.5 \text { shelter } \\
\text { coefficient }\end{array}$ & All & 0.25 & $\begin{array}{l}\$ / \mathrm{ft}^{2} \\
\text { finished } \\
\text { floor }\end{array}$ & & \\
\hline & Mechanical ventilation & Exhaust & All & 1100 & $\$$ & & \\
\hline \multirow{5}{*}{$\begin{array}{c}\text { Major } \\
\text { Appliances }\end{array}$} & Refrigerator & Benchmark & All & 1100 & $\$$ & & \\
\hline & Cooking range & Benchmark & All & 920 & $\$$ & & \\
\hline & Dishwasher & Benchmark & All & 880 & $\$$ & & \\
\hline & Clothes washer & Benchmark & All & 590 & $\$$ & & \\
\hline & Clothes dryer & Benchmark & All & 760 & $\$$ & & \\
\hline Lighting & Lighting & Benchmark & All & 0.04 & $\begin{array}{l}\$ / \mathrm{ft}^{2} \text { living } \\
+ \text { garage }\end{array}$ & & \\
\hline \multirow{7}{*}{$\begin{array}{c}\text { Space } \\
\text { Conditioning }\end{array}$} & Central air conditioner & SEER 13 & All & 64 & $\$ / \mathrm{kBtu} / \mathrm{h}$ & 410 & \$ (labor) \\
\hline & Furnace & Gas, $78 \%$ AFUE & All & 9 & $\$ / \mathrm{kBtu} / \mathrm{h}$ & 1200 & \$ (labor) \\
\hline & Boiler & None & All & 0 & $\$$ & & \\
\hline & Electric baseboard & None & All & 0 & $\$$ & & \\
\hline & Air source heat pump & None & All & 0 & $\$$ & & \\
\hline & Ground source heat pump & None & All & 0 & $\$$ & & \\
\hline & Ducts & $15 \%$ leakage, R-6 & All & 5.8 & $\begin{array}{l}\$ / \mathrm{ft}^{2} \text { duct } \\
\text { surface }\end{array}$ & & \\
\hline
\end{tabular}

\footnotetext{
${ }^{9}$ Overhangs are defined as the shading provided over each window. The Benchmark building does not have overhangs.
} 
u.s. DEPARTMENT OF | Energy Efficiency \&

Renewable Energy

\begin{tabular}{|c|c|c|c|c|c|c|c|}
\hline & Ceiling fan & Benchmark & All & 240 & $\$ /$ fan & 290 & $\begin{array}{l}\text { \$/fan } \\
\text { (labor) }\end{array}$ \\
\hline & Dehumidifier & None & All & 0 & $\$$ & & \\
\hline \multirow{5}{*}{$\begin{array}{l}\text { Water } \\
\text { Heating }\end{array}$} & Water heater & Benchmark & All & 10 & \$/gal & 640 & $\$$ \\
\hline & Distribution & $\begin{array}{c}\text { Uninsulated, } \\
\text { TrunkBranch, copper }\end{array}$ & All & 8.6 & \$/ft Piping & & \\
\hline & Solar water heating & None & All & 0 & $\$$ & & \\
\hline & Solar water heating azimuth & Back roof & All & 0 & $\$$ & & \\
\hline & Solar water heating tilt & Roof pitch & All & 0 & $\$$ & & \\
\hline $\begin{array}{c}\text { Power } \\
\text { Generation }\end{array}$ & None & & & 0 & $\$$ & & \\
\hline
\end{tabular}




\section{Clarification 4.2-Cash Flow Assumptions}

There have also been requests to state explicitly what the cash flow assumptions are for the Benchmark and retrofit analyses. These values are documented in Table 10 and are consistent with the default values in BEopt.

Table 10. Cash Flow Assumptions

\begin{tabular}{c|c|c|c}
\hline \multirow{2}{*}{ Group } & Category & Construction Type & Value \\
\hline \multirow{4}{*}{ Economics } & Project analysis period & All & 30 years \\
\cline { 2 - 4 } & Inflation rate & All & $3.0 \%$ \\
\cline { 2 - 4 } & Discount rate & All & $3.0 \%$ \\
\cline { 2 - 4 } & Down payment & $\begin{array}{c}\text { New, existing with loan, and } \\
\text { existing with tax deductible loan }\end{array}$ & $0.0 \%$ \\
\cline { 2 - 4 } & Mortgage interest rate & Existing, cash & $100 \%$ \\
\cline { 2 - 4 } & Mortgage/loan period & All applicable & $30 \%$ \\
\cline { 2 - 4 } & \multirow{3}{*}{ Mortgagears } \\
\cline { 2 - 4 } & Marginal income tax rate, & New & 5 years \\
\cline { 2 - 4 } & federal & tax deductible loan & $28 \%$ \\
\hline
\end{tabular}

The analyst should use OpenEI to find whatever utility rate is the closest to the actual rate the homeowner pays. This is applicable to all analyses, including for the Benchmark, NCTH, and pre- and post-retrofit. The site to source ratios for electricity, gas, propane, and oil are 3.365, $1.092,1.151$, and 1.158 , respectively in all locations and are automatically implemented in BEopt.

\footnotetext{
${ }^{10}$ The analysis period versus the mortgage period for existing homes is part of a larger, ongoing discussion about how to report on energy savings metrics in existing homes. This will be discussed further in 2013.
} 


\section{Overall Document Format}

\section{Recommendation 5.1.1-Internal Versus External}

Although the BA HSP document was never meant for use outside of the BA program, some people reference its values simply because few such references are available.

There have been some suggestions for a change in the overall report format. Some believe that the report would benefit from a division of information. There would be two reports to represent the current HSP, one internal to the BA program, and one external for all simulation analysts. In cases where not enough research has been done to provide a recommendation to outside users, the external version of the HSP would be silent.

Pros: It would be clear to outside users which values have proper justification for general use. All values that are meant only for programmatic calculations would be used only for the BA program, as was the original intent.

Cons: The magnitude of effort required for such a task is unclear. However, the report used by outside stakeholders would be fairly short, because there are few statistically significant values for simulation assumptions in the current version.

At this point, the report will remain the same because of budget constraints. However, feedback on this possible division is welcomed by the authors.

\section{Recommendation 5.1.2-Directions versus Justifications}

There are also discussions about the usefulness of the current written format, which consists of tables of data, followed by explanations and justifications. One suggestion was to break the report into two parts. The first part would be similar to an executive summary with only short tables of information for how to model the benchmark or retrofit building. The descriptions and justifications would be provided in the main body of the report. It has also been suggested that a separate report be created to describe only the operating conditions and corresponding separate section for the justification for those values.

Pros: It will be easier for an analyst to choose inputs for any modeling program and know which values to use for the Benchmark without having to read the entire report.

Cons: The magnitude of effort required for such a task is unclear. Separating the two elements might promote inappropriate use of some of the assumptions that are detailed in this report.

At this point, the report will remain the same because of budget constraints. However, feedback on this possible division is welcomed by the authors. 


\section{Bibliography}

Abrams, D.W.; Shedd, A.C. (1996). "Effect of Seasonal Changes in Use Patterns and Cold Inlet Water Temperature on Water Heating Load.” ASHRAE Transactions, AT-96-18-3.

Aquacraft. (2008). "Hot \& Cold Water Data from EPA Retrofit Studies_EBMUD \& Seattle." Boulder, CO: Aquacraft Inc.

ASHRAE. (2009). Handbook-Fundamentals. Atlanta, GA: American Society of Heating, Refrigerating and Air-Conditioning Engineers.

ASHRAE. (2008). HVAC Systems and Equipment Handbook. Atlanta, GA: American Society of Heating, Refrigerating and Air-Conditioning Engineers.

ASHRAE. (2007a). Ventilation and Acceptable Indoor Air Quality in Low-Rise Residential Buildings. ASHRAE Standard 62.2-2007, Atlanta, GA: American Society of Heating, Refrigerating and Air-Conditioning Engineers.

ASHRAE. (2007b). HVAC Applications Handbook. Atlanta, GA: American Society of Heating, Refrigerating and Air-Conditioning Engineers.

ASHRAE. (2004a). Method of Test for Determining the Design and Seasonal Efficiencies of Residential Thermal Distribution Systems, ASHRAE Standard 152-2004, Atlanta, GA: American Society of Heating, Refrigerating and Air-Conditioning Engineers.

ASHRAE. (2004b). "Thermal Environmental Conditions for Human Occupancy," ASHRAE Standard 55-2004, Atlanta, GA: American Society of Heating, Refrigerating and AirConditioning Engineers.

ASHRAE. (1993). A Method of Determining Air Change Rates in Detached Dwellings, ASHRAE Standard 136-1993, Atlanta, GA: American Society of Heating, Refrigerating and AirConditioning Engineers.

ASHRAE. (1988). Air Leakage Performance for Detached Single-Family Residential Buildings, ASHRAE Standard 119-1988, Atlanta, GA: American Society of Heating, Refrigerating and AirConditioning Engineers.

ASTM. (1994). Moisture Control in Buildings. Conshohocken, PA: American Society for Testing and Materials.

ASTM. (2007). Standard Test Methods for Determining External Air Leakage of Air Distribution Systems by Fan Pressurization. ASTM E1554-07. Conshohocken, PA: American Society for Testing and Materials.

ASTM. (2003). Standard Test Method for Determining Air Leakage Rate by Fan Pressurization. ASTM E779-03. Conshohocken, PA: American Society for Testing and Materials.

AWWA. (1999). "Residential End Uses of Water." Denver, CO: American Water Works Association AWWA.

Becker, B.R.; Stogsdill, K.E. (1990). "Development of Hot Water Use Data Base." ASHRAE Transactions 96(2):422-427. Atlanta, GA: American Society of Heating, Refrigerating and Air Conditioning Engineers. 
Burch, J.; Christensen, C. (2007). "Towards Development of an Algorithm for Mains Water Temperature.” In Proceedings of the 2007 ASES Annual Conference, Cleveland, OH.

Burch, J.; Erickson, P. (2004). "Using Ratings Data to Derive Simulation-Model Inputs for Storage-Tank Water Heaters." 2004 National Solar Energy Conference. Boulder, CO: American Solar Energy Society.

Burch, J.; Salasovich, J. (2002). "Flow Rates and Draw Variability in Solar Domestic Hot Water Usage." In Proceedings of the Solar 2002 Conference Including Proceedings of the 31st ASES Annual Conference and Proceedings of the 27th National Passive Solar Conference, 15-20 June 2002, Reno, Nevada. Boulder, CO: American Solar Energy Society, Inc.; pp. 287-292; Golden, Colorado: National Renewable Energy Laboratory, NREL Report No. CP-550-31779.

California Energy Commission (CEC). (2010). Appliance Efficiency Database. http://www.appliances.energy.ca.gov/. Sacramento, CA: California Energy Commission. Last accessed September 2010.

California Energy Commission (CEC). (2002). California Building Energy Efficiency Standards, Part 1, Measure Analysis and Life Cycle Cost. Sacramento, CA: California Energy Commission.

Christensen, C.; Anderson, R.; Horowitz, S.;Courtney, A; Spencer, J. (2006). "BEopt Software for Building Energy Optimization: Features and Capabilities." Golden, CO: National Renewable Energy Laboratory, NREL Reprot No. TP-550-39929.

Christensen, C.; Barker, G.; Thornton, J. (2000). "Parametric Study of Thermal Performance of Integral Collector Storage Solar Water Heaters.” Golden, CO: National Renewable Energy Laboratory, NREL Report No. CP-550-28043.

DEG. (2006). Prototype Floor Plans-Hot Water Distribution System Layouts. Report to Lawrence Berkeley National Laboratory under funding by the California Energy Commission. Davis, CA: Davis Energy Group.

Deru, M.; Torcellini, P. (2007). Source Energy and Emission Factors for Energy Use in Buildings. Golden, CO: National Renewable Energy Laboratory, NREL/TP-550-38617.

DOE. (2010). Residential Heating Products Final Rule Technical Support Document. Chapter 7: Energy Use Characterization. http://www1.eere.energy.gov/buildings/appliance standards/ residential/heating_products_fr_tsd.html. Washington, DC: U.S. Department of Energy. Last accessed May 2012.

DOE. (2005). “2005 Residential Energy Consumption Survey.” www.eia.doe.gov/emeu/ recs/contents.html. Washington, DC: U.S. Department of Energy. Last accessed August 2010.

DOE. (2004). Code of Federal Regulations Title 10, Energy, Part 430, Subpart B, Appendices C, D, J, and J1, Washington, DC: U.S. Department of Energy.

DOE. (2004a). Technical Support Document: Energy Efficiency Program for Consumer Products: Energy Conservation Standards for Residential Furnaces and Boilers. www.eere.energy.gov/buildings/appliance_standards/residential/furnaces_boilers.html. Washington, DC: U.S. Department of Energy. Last accessed June 2010.

DOE. (2004b). 2004 Buildings Energy Databook. http://btscoredatabook.eren.doe.gov/. Washington, DC: U.S. Department of Energy. Last accessed June 2010. 
DOE. (2003a). New and Alternative Insulation Materials and Products. Energy Savers Fact Sheet. www.eere.energy.gov/consumerinfo/factsheets/eb9.html (accessed August 2005). Washington, DC: U.S. DOE.

DOE. (2003b). Appliances and Commercial Equipment Standards. www.eere.energy.gov/ buildings/ appliance_standards/. Washington, DC: U.S. Department of Energy. Last accessed May 2004.

DOE. (2002a). Technical Support Document: Energy Efficiency Standards for Consumer Products: Residential Central Air Conditioners and Heat Pumps. www.eere.energy.gov/ buildings/appliance_standards/residential/central_ac_hp.html. Washington, DC: U.S. Department of Energy. Last accessed June 2010.

DOE. (2002b). Residential Energy Efficiency and Appliance Standards. www.eere.energy.gov/ consumerinfo/refbriefs/ee8.html. Washington, DC: U.S. Department of Energy. Last accessed May 2004.

DOE. (2001a). Code of Federal Regulations Title 10, Energy, Part 430, Energy Conservation Program for Consumer Products: Energy Conservation Standards for Water Heaters; Final Rule. www1.eere.energy.gov/buildings/appliance_standards/residential/pdfs/water_heater_fr.pdf. Washington, DC: U.S. Department of Energy. Last accessed August 2010.

DOE. (2001b). Residential Energy Consumption Survey. Washington, DC: U.S. Department of Energy.

DOE. (2001). Annual Energy Outlook 2002. Washington, DC: U.S. Department of Energy.

DOE. (2000a). Technical Support Document: Energy Efficiency Standards for Consumer Products: Residential Water Heaters. Appendix D-2. www.eere.energy.gov/buildings/ appliance_standards/residential/waterheater.html. Washington, DC: U.S. Department of Energy. Last accessed June 2010.

DOE. (2000b). Final Rule Technical Support Document: Energy Efficiency Standards for Consumer Products: Clothes Washers. www.eere.energy.gov/buildings/appliance standards/ residential/clothes_washer.html. Washington, DC: U.S. Department of Energy. Last accessed June 2010.

DOE. (1999). “1997 Residential Energy Consumption Survey.” www.eia.doe.gov/emeu/ recs/pubs.html Washington, DC: U.S. Department of Energy. Last accessed December 2009).

DOE. (1997). Code of Federal Regulations Title 10, Energy, Part 430, "Energy Conservation Program for Consumer Products: Test Procedure for Kitchen Ranges, Cooktops, Ovens, and Microwave Ovens; Final Rule.” Washington, DC: U.S. Department of Energy.

DOE. (1996). Residential Lighting Use and Potential Savings. DOE/EIA-0555(96)/2. Washington, DC: U.S. Department of Energy.

DOE. (1995). Measuring Energy Efficiency in the United States Economy: A Beginning. Chapter 7. www.eia.doe.gov/emeu/efficiency/ee_report_html.htm. Washington, DC: U.S. U.S. Department of Energy. Last accessed June 2010.

DOE. (1993). Technical Support Document for Residential Cooking Products. Volume 2. www.eere.energy.gov/buildings/appliance_standards/residential/cooking_products_0998_r.html. Washington, DC: U.S. Department of Energy. Last accessed June 2010. 
EPRI. (1986). Trends in the Energy Efficiency of Residential Electric Appliances. EM-4539, Research Project 2034-9. Palo Alto, CA: Electric Power Research Institute.

EPRI. (1987). TAG Technical Assessment Guide: Volume 2: Electricity End Use. EPRI P-4463-

SR. Palo Alto, CA: Electric Power Research Institute.

E-Source. (1993). Space Heating Technology Atlas. Boulder, CO: E-Source Inc.

E-Star Colorado. (2005). R-Value Table. www.e-star.com/ecalcs/table_rvalues.html. Last accessed August 2005.

Gleick, P.H.; Haasz, D.; Henges-Jeck, C.; Srinivasan, V.; Wolff, G.; Kao-Cushing, K.; Mann, A. (2003). Waste Not, Want Not: The Potential for Urban Water Conservation in California.

Prepared for Pacific Institute for Studies in Development, Environment and Security. Oakland, CA.

Greening, L.A.; Greene, D.L.; Difiglio, C. (2000). Energy Efficiency and Consumption-The Rebound Effect—A Survey. Energy Policy 28:389-401. Amsterdam, Netherlands: Elsevier B.V.

Hancock, E.; Norton, P.; Hendron, R. (2002). Building America System Performance Test Practices: Part 2, Air-Exchange Measurements. NREL/TP-550-30270. Golden, CO: National Renewable Energy Laboratory.

Hendron, R. (2008). Building America Research Benchmark Definition Updated December 19, 2008. NREL/TP-550-44816. Golden, CO: National Renewable Energy Laboratory.

Hendron, R.; Eastment, M. (2006). "Development of an Energy-Savings Calculation Methodology for Residential Miscellaneous Electric Loads.” ACEEE Summer Study on Energy Efficiency in Buildings. Washington, DC: American Council for an Energy-Efficient Economy.

Huang, J.; Gu, L. (2002). Prototype Residential Buildings to Represent the U.S. Housing Stock. Draft LBNL Report. Berkeley, CA: Lawrence Berkeley National Laboratory.

HUD. (1982). "Minimum Property Standards for One- and Two-Family Living Units." No. 4900.1-1982. Washington, DC: U.S. Department of Housing and Urban Development.

ICC. 2003. International Energy Conservation Code 2003. Falls Church, VA: International Code Council.

Jiang, W.; Jarnagin, R.E.; Gowri, K.; McBride, M.; Liu, B. (2008). Technical Support Document: The Development of the Advanced Energy Design Guide for Highway Lodging Buildings. Richland, WA: Pacific Northwest National Laboratory.

Judkoff, R.; Balcomb, J. D.; Hancock, C. E.; Barker, G.; Subbarao, K. (2000). Side-By-Side Thermal Tests of Modular Offices: A Validation Study of the STEM Method. Golden, CO: National Renewable Energy Laboratory. NREL/TP-550-23940.

KEMA. (2009). "Residential Lighting Metering Study: Preliminary Results." February 2009 Presentation to Stakeholders. Oakland, CA: KEMA. www.energydataweb.com/cpuc/home.aspx. Kolb, G. (2003). Private communication. Albuquerque, NM: Sandia National Laboratories.

Lithgow, M.; Filey, D.; Kaszczij, R.; Liotta, J.; Den-Elzen, P. (1999). Multi-Unit Residential Clothes Washer Replacement Pilot Project. Prepared by the City of Toronto Works and Emergency Services and the Toronto Community Housing Corporation, Toronto, Canada. 
Lstiburek, J. (1999). Heating Choices. Research Report—9911. Somerville, MA: Building Science Corporation. http://www.buildingscience.com/documents/reports/rr-9911-heating$\underline{\text { choices }}$

Matson, N.; Wray, C.; Walker, I.; Sherman, M. (2002). Potential Benefits of Commissioning California Homes. LBNL-48258. Berkeley, CA: Lawrence Berkeley National Laboratory.

Mills, E. 2008. The Home Energy Saver: Documentation of Calculation Methodology, Input Data, and Infrastructure, LBNL-51938. Berkeley, CA: Lawrence Berkeley National Laboratory.

Navigant Consulting. (2002). U.S. Lighting Market Characterization: Volume 1: National Lighting Inventory and Energy Consumption Estimate. Washington, DC: Navigant Consulting.

NRC. (2002). “A National Study of Water \& Energy Consumption in Multifamily Housing: InApartment Washers vs. Common Area Laundry Rooms.” Multi-housing Laundry Association. Boulder, CO: National Research Center.

NREL. (2009). "Benchmark Midrise Apartment NewV1(2).1_3.1(SI).” Golden, CO: National Renewable Energy Laboratory.

Parker, D.; Fairey, P.; Hendron, R. (2010). Updated Miscellaneous Electricity Loads and Appliance Energy Usage Profiles for Use in Home Energy Ratings, the Building America Benchmark Procedures and Related Calculations. FSEC-CR-1837-10. Cocoa, FL: Florida Solar Energy Center.

Parker, D. (2002). Research Highlights from a Large Scale Residential Monitoring Study in a Hot Climate (and personal communication). FSEC-PF369-02. Cocoa, FL: Florida Solar Energy Center.

Parker, D.; Sherwin, J.R.; Anello, M.T. (2000). FPC Residential Monitoring Project: Assessment of Direct Load Control and Analysis of Winter Performance. Prepared for the Florida Power Corporation, Cocoa, FL, FSEC-CR-1112-99.

PNNL; ORNL. (2007). High-Performance Home Technologies: Guide to Determining Climate Regions by County. Building America Best Practices Series. http://apps1.eere.energy.gov/ buildings/publications/pdfs/building_america/climate_region_guide.pdf. Richland, WA: Pacific Northwest National Laboratory. Last accessed July 2010.

Pratt, R.; Conner, C.; Richman, E.; Ritland, K.; Sandusky, W.; Taylor, M. (1989). Description of Electric Energy Use in Single-Family Residences in the Pacific Northwest-End-Use Load and Consumer Assessment Program, Richland, WA: Pacific Northwest National Laboratory, DOE/BP-13795-21.

Rea, M., et al. (2000). Lighting Handbook, Ninth Edition. New York, NY. Section 3, Chapter 10: Illuminance Selection.

RESNET. (2006). 2006 Mortgage Industry National Home Energy Rating Systems Accreditation Standards. San Diego, CA: Residential Energy Services Network.

Sachs, H.M. (2005). Opportunities for Elevator Energy Efficiency Improvements. Washington D.C.: American Council for an Energy-Efficient Economy. 
Sherman, M.H.; Grimsrud, D.T. (1980). "Infiltration-Pressurization Correlation: Simplified Physical Modeling." ASHRAE Transactions 86(2):778. Atlanta, GA: American Society of Heating, Refrigerating and Air-Conditioning Engineers.

SWA. (1995). Simplified Multizone Blower Door Techniques for Multifamily Buildings. NYSERDA Report \# 95-16. Norwalk, CT: Steven Winter Associates, Inc..

Stokes, M.; Rylatt, M.; Lomas, K. (2004). “A Simple Model of Domestic Lighting Demand.” Energy and Buildings 36:103-116. United Kingdom: Institute of Energy and Sustainable Development.

Szydlowski, R.; Cleary, P. (1988). "In-Situ Appliance Efficiency Audit Procedures." ASHRAE Transactions 94(1):1107-1023. Atlanta, GA: American Society of Heating, Refrigerating and Air-Conditioning Engineers.

Taylor, Z.T.; Conner, C.C.; Lucas, R.G. (2001). "Eliminating Window-Area Restrictions in the IECC.” Report No. PNNL-SA-35432. Richland, WA: Pacific Northwest National Laboratory.

Wassmer, M. (2003). A Component-Based Model for Residential Air Conditioner and Heat Pump Energy Calculations. Masters Thesis, University of Colorado at Boulder.

Wenzel, T.; Kooney, J.; Rosenquist, G.; Sanchez, M.; Hanford, J. (1997). Energy Data Sourcebook for the U.S. Residential Sector. Berkeley, CA: Lawrence Berkeley National Laboratory, LBL-40297. 


\section{U.S. DEPARTMENT OF Energy Efficiency \& ENERY Renewable Energy}

